\title{
BRANDING AS AN ESSENTIAL ELEMENT OF THE OF DESTINATION MANAGEMENT PROCESS USING THE EXAMPLE OF SELECTED STATES
}

\author{
Mirosław Marczak \\ WSB Universities, Gdańsk, Poland \\ e-mail: miromilan@wp.pl \\ (C) 2018 Mirosław Marczak \\ This is an open access article distributed under the Creative Commons Attribution-NonCommercial-NoDerivs license \\ (http://creativecommons.org/licenses/by-nc-nd/3.0/) \\ DOI: $10.15611 / \mathrm{ms} .2018 .2 .04$ \\ JEL Classification: L83, M31
}

\begin{abstract}
With reference to the current situation of national public hospitals, the article presents the possibility to implement the Lean Management concept in hospital management. Numerous common features connecting the management of commercial entities with the management of healthcare institutions are indicated. It has been stated that the management of contemporary organizations, regardless of the type of conducted operations, needs to focus on customer/patient satisfaction, financial liquidity and high quality. The purpose of the article is to assess the possibility to implement the Lean Management concept in hospitals. In particular, an attempt was made on the basis of a pilot survey to assess the introduction of the above concept in two selected hospitals. Critical analysis of the literature on the subject, the analysis of research results of other authors, casual interview, observation of practice as well as a survey based on the prepared questionnaire were used to achieve the purpose.
\end{abstract}

Keywords: branding, brand, management of the area of tourist reception, national tourist organization (NTO).

\section{Introduction}

Although the notion of branding has been functioning for a relatively short period in the literature of the subject, branding has been justly recognized as a very effective way to obtain a possible improvement of quality, and to increase the rank and effectiveness of the selected tourist sectors. Over the past two decades, branding has become an important element that forms the marketing approach which consists in the cooperation of the many stakeholders who need to cooperate in order to achieve the desired result in the tourism reception area brand management process [Green 2005].

Branding constitutes one of the most important areas of the activities of modern national tourism organizations (NTO). Undoubtedly, it is one of the key elements in the competition between tourist destinations. However, it should be clearly emphasized that this is a long-term and multi-dimensional process, one which involves a number of aspects related to the functioning of the present-day areas of tourist reception. Furthermore, it involves aspects of the functioning of various social groups. As mentioned previously, branding now constitutes an essential element in the competition between regions while simultaneously being an indicator for tourists of the quality level of the services offered in a given area. For this very reason, the activities undertaken within the framework of branding are becoming the most important element that remains under the control of those who manage tourist reception areas. It is the activities of national tourist organizations that are of particular importance here. They are responsible for the promotion of national destinations on the international market.

The term "branding" is very often identified with the brand, which is not legitimate. This is a certain narrowing of a concept which does not present the entire process of the creation and impact of the brand. 
The creation of a brand on the market should not be considered merely as actions that are limited to names and symbols. It requires the use of many functional and tool strategies, whereas properly understood branding is in reality a synonym of marketing but with respect to the brand.

Due to the interdisciplinary and multifaceted nature of branding, and its real effectiveness and market efficiency, numerous authors have taken up this issue (including [Aaker 2002; Anholt 2009, 2010; Anholt, Spaven 2009; Ashworth 2010, Boyle 2003; Cliffton, Simmons 2004; de Chernatony, McDonald 2003; Dinnie 2008; Fan 2006; Gabrielsson 2005; Govers 2009; Govers, Go 2009; Kavaratzis, Ashworth 2008; Majewski 2007; 2012; Marczak 2016a; 2016b; 2017; Pike 2008; 2009; Pike, Page 2014; Tesławski 2013; Żemła 2009; 2012]. It should also be emphasized that interest in this issue may follow from the fact that branding possesses a universal nature. It can be used both in relation to an enterprise and a tourist destination (e.g. a region or a country) and its tourist products. However, in the latter case, there is a widespread belief that first a given tourist destination should possess a product(s) so that one can commence building brand awareness.

The notion of the tourism reception area was introduced into tourist terminology in the 1970s [Kesić, Pavlić 2011]. The point of departure for many studies in this area included among others the papers by R. Butler [1980] related to the tourist place life cycle or the studies by E. Inskeep [1994] concerning planning in the tourism reception area [Borzyszkowski 2015]. At the end of the past century, new aspects began to appear in the concept of the tourism reception area, including the environmental impact of the functioning of such areas and the use of marketing activities for the purposes of the tourism reception area.

The tourist reception area is a place which attracts visitors for a temporary stay. This can be a country, a province, a region, a town or a village [Dębski 2013]. This approach is expanded by the UNWTO while indicating that the local tourism reception area is a space where the tourist spends at least one night; it consists both of attractions and any services required to enable a stay for the tourist [Ipsas 2012]. This approach is certainly justifiable because it indicates the components of the product of the destination. A. Niezgoda [2006], while emphasizing the functional nature of a separated area, emphasizes that the scope of the area defined as a destination varies depending on the purpose and motive of the trip. However, it should be emphasized that the notion of the tourist reception area is diversely defined in the national and foreign source literature. At the same time, some of the authors including [Manente, Minghetti 2006; Nawrocka 2008; Page, Connell 2009] consider the tourism reception area in the categories of the tourism product that possesses its own recognized brand ([including Middleton, Hawkins 1998]).

As stated by M. Marczak and J. Borzyszkowski [2015], the tourism reception area and any activities aimed at the promotion of its brand should be considered in the categories of the tourism product. Bearing in mind the idea of the phenomenon of tourism and the recently formed supply structure, a definition of this type of product is more difficult than in other fields. The basic problem is that various entities that operate on the tourism market perceive this product in different ways. The concept of the product of the tourism reception area is one of the attempts of the proper definition of the tourism product considering the spatial aspect which is essential in territorial marketing. In accordance with this, the product of the tourism reception area can be defined as an entirety consisting of tangible and intangible elements that constitute the base of the image in the tourist's mind and their expectations connected with a stay in a given place [Dziedzic 1998].

For better clarity, it should be emphasized that the notions of the product of the tourism reception area should not be equated with the tourist supply in a given area. Talking about the product, its individual elements should be subordinated to the joint concept aimed at satisfying the tourist's needs. This means that the same area may offer several products addressed to different groups of recipients, and the proper selection of their range is one of the most important problems of management. In the activities in this scope, an essential role is attributed to the public sector. For example, E. Dziedzic [2012] believes that the creation of a comprehensive product, e.g. for a town, is practically impossible without the involvement of the public sector because such a product involves those elements which, first of all, the state is responsible for (e.g. the external appearance of a place, safety and transport).

The management process of the tourism reception area is extremely complex. A particular role in this respect is attributed to the activities aimed at the creation of a positive image of the tourist area and building a strong brand of the region. In the view of many authors, the development of branded products based on the most important natural and anthropogenic values undoubtedly contributes to an improved image and thereby, the increased competitiveness of its offered range of tourist attractions. It is branded products that help one to enhance and increase the so-called perceived attraction. A particular role in 
this respect is attributed to activities undertaken by those that manage destinations within the framework of branding. This notion is to be understood as all activities aimed at building the brand awareness of a given tourism reception area in recipients' perception. These days, branding has very quickly been recognized as an effective manner to quickly obtain an improvement of the quality and an increase of the rank and effectiveness of selected tourist sectors. Within the past two decades, it has also become an important element in shaping a marketing approach that consists in cooperation between many heterogeneous stakeholders that should cooperate with a view to achieve the desirable result in the tourism reception area management process.

\section{Concept of branding for the tourist reception area in source literature}

A deepening interest on the part of scholars in the branding of the tourism reception area was observed at the beginning of the $21^{\text {st }}$ century. Attributing to the region typically attractive features characteristic only for this area, and which are explicitly recognizable and carry values appreciated by the market, is the main assumption of destination branding [Analiza wyników... 2008]. In the literature there are diverse approaches to the definition of the "destination branding" notion (see Table 1).

Table 1. Definition of the branding of tourist destinations according to selected authors

\begin{tabular}{|l|l|}
\hline \multicolumn{1}{|c|}{ Author(s) } & \multicolumn{1}{c|}{ Definition } \\
\hline $\begin{array}{l}\text { C. Blain, } \\
\text { S.E. Levy, } \\
\text { J.R.B. Ritchie }\end{array}$ & $\begin{array}{l}\text { Activities that involve the creation of a logo } \\
\text { and various graphical symbols, whose } \\
\text { purpose is the identification of a given } \\
\text { destination as compared to others. These } \\
\text { activities are aimed at the fulfilment of the } \\
\text { promise of memorable experiences from } \\
\text { trips that are explicitly connected with } \\
\text { a given destination }\end{array}$ \\
\hline A. Cai & $\begin{array}{l}\text { A process that consists in the proper } \\
\text { selection of cohesive elements that compose } \\
\text { a given tourism reception area in order to } \\
\text { distinguish it from competing areas with the } \\
\text { use of activities that build a positive image }\end{array}$ \\
\hline $\begin{array}{l}\text { C. Goeldner, } \\
\text { J. Ritchie, } \\
\text { R.W. MacIntosh }\end{array}$ & $\begin{array}{l}\text { Activities aimed at the fulfilment of the } \\
\text { promises of memorable experiences, ones } \\
\text { which will explicitly be connected with the } \\
\text { trip's destination. These activities are also } \\
\text { aimed at enhancing pleasant associations } \\
\text { connected with the given destination in } \\
\text { tourists' minds }\end{array}$ \\
\hline $\begin{array}{l}\text { Khese involve the concept of a combination } \\
\text { Ch. Vogtanidou, all the attributes connected with the given }\end{array}$ \\
\hline
\end{tabular}

\begin{tabular}{|c|c|}
\hline & $\begin{array}{l}\text { destination (including products, services, } \\
\text { investments, technologies, education) in } \\
\text { order to depict a unique identity and nature } \\
\text { of the destination. This requires a cohesive } \\
\text { vision, mission and specified goals }\end{array}$ \\
\hline $\begin{array}{l}\text { J.B. Ritchie, } \\
\text { R.J.B. Ritchie }\end{array}$ & $\begin{array}{l}\text { A set of marketing activities whose goals } \\
\text { include the following: } \\
\text { - support of the creation of the name, } \\
\text { symbols, logo, graphical signs that easily } \\
\text { distinguish the given destination from } \\
\text { others, } \\
\text { - passing on to recipients the expectations of } \\
\text { memorable trips connected with the } \\
\text { destination, } \\
\text { - consolidation and enhancing emotional } \\
\text { bonds between tourists and the destination, } \\
\text { minimization of the costs and risks } \\
\text { connected with decisions made by tourists } \\
\text { in connection with the selection of } \\
\text { destinations }\end{array}$ \\
\hline G. Szondi & $\begin{array}{l}\text { This involves activities aimed at the } \\
\text { promotion of a given country that contribute } \\
\text { to its improved tourism image and that } \\
\text { support building a strong national brand }\end{array}$ \\
\hline A. Tan & $\begin{array}{l}\text { This is a combination of philosophy and its } \\
\text { realization. This consists in triggering off } \\
\text { a desirable effect in relation to the } \\
\text { perception of the destination in people's } \\
\text { minds with the use of specific } \\
\text { communication techniques }\end{array}$ \\
\hline H. Uhrenholt & $\begin{array}{l}\text { A process that consists in developing } \\
\text { a unique identifier that distinguishes a given } \\
\text { destination from the competiting areas. This } \\
\text { identifier should consist of the following } \\
\text { attributes among others: attractions, arts, } \\
\text { technology, brand identity, individual sectors } \\
\text { of the economy, known and valued } \\
\text { personalities etc. }\end{array}$ \\
\hline
\end{tabular}

Source: author's own study based on [Bakri, Soliman, Al Bohairy 2010; Blain, Levy, Ritchie 2005; Cai 2002; Cretu 2011; Goeldner, Ritchie, MacIntosh 2000; Kaplanidou, Vogt 2003; Ritchie, Ritchie 1998; Rizvi, Ahmad 2012; Szondi 2006; Tan 2008; Uhrenholt 2008].

A review of the definitions quoted above makes it possible to identify the main advantages according to "destination branding":

- contributes to an increase of the polarization of the tourism reception area market, which translates onto facilities for tourists when they are making their selections,

- helps to reduce the risk connected with the selection of a given tourism reception area as the destination of a tourist trip,

- is a guarantee of a cohesive and coordinated message and a guarantee of quality in many tourism reception area places in the same time, 
- reduces the level of risk that is so characteristic when making an initial decision concerning an intention to undertake a tourist trip,

- enables a precise segmentation of the market,

- is a tool that enables the integration of the efforts undertaken by various entities that function within the framework of a given tourism reception area aimed at the achievement of a common success [Aziz, Kefallonitis, Friedman 2012].

An analysis of the aforementioned definitions of the "destination branding" notion furthermore enables an indication of certain elements and features which are common for them, i.e.:

- an increase of knowledge of the identity of the tourism reception area and an improvement of its image,

- creation of the future identity of the tourism reception area,

- making promises and an ability to fulfil them with the simultaneous maintenance of the degree of perception of the tourism reception area brand,

- giving a specific "spirit" to the tourism reception area, which additionally stimulates the recipients' awareness,

- generation of an additional value through the creation of emotional (intangible) and functional attributes of the tourism reception area brand,

- creation of unique emotional associations,

- introduction in recipients' awareness of an image that shows qualitative differences in relation the products offered by competing regions [Skoko, Kovacic 2009].

In the specialist literature, a view can be found stating that branding constitutes one of the more important elements in the tourism reception area management process. The results of research by L. Padurean [2010] may prove this. It is evident, based on them, that $74.2 \%$ of all Destination Management Organizations (DMOs) indicate that branding is the most important sphere of their activities as, according to their opinions, it is the only element which they are able to fully control [Borzyszkowski 2015]. There is also an approach which states that branding constitutes the DNA of each destination [Handbook on Tourism... 2009]. A. Pritchard and N. Morgan [1998], while emphasizing the significance of the present-day branding for tourist destinations, found that nowadays the struggle for the customer in the tourist branch takes place not based on the price but on tourists' hearts and minds. Therefore, the functioning of the brands of the tourist destination will be the key to success. These three statements seem to confirm the significance of branding for the functioning of the present-day tourist reception areas.
Due to the scope of activities, destination branding may occur on various levels, i.e. international, national, regional and local [Henderson 2007]. However, regardless of the level on which branding is realized, it is essential that tourists visiting given places feel emotional bonds with them [Morgan, Pritchard, Piggott 2002]. The most important objectives of the tourism reception area branding include the following:

- passing on information to potential tourists about the unique identity of a tourism reception area,

- creation of the core of benefits for customers to trigger the feeling of loyalty with the current customers and acquisition of new customers,

- diversification of a destination as compared to competing areas,

- unification of message on behalf of all the stakeholders of a tourism reception area,

- support of the creation of names, symbols, logo, graphical signs that identify a given destination,

- designing and building the awareness of a strong tourism reception area brand among recipients as a tool in the social and economic development of a given area [Uhrenholt 2008].

Those elements that play a key role in the structure of "destination branding" include the following:

- identity of the brand of the destination: an element of an active part of the building process of the tourist reception area image which involves a unique set of associations with a given area [Rainisto 2007],

- positioning the brand of the destination: an activity connected with the formation of the offered product and the image of a tourism reception area, which creates its image among tourists which will be distinguishable in relation to competitive areas,

- an image of the brand of the destination: that constitutes the base of the brand's identification together with tourists' experiences [Pike 2008].

The concept mentioned above was expanded by J. Ndlovu [2009], who added activities taken within the framework of widely understood marketing and communication to the three aforementioned elements. According to this author, this concept was known as a "destination branding funnel", presenting the most important elements which decide about the achievement of the elementary assumptions of "destination branding".

Present-day branding demonstrates strong connections with two elements of marketing-mix, i.e. the product and promotion. The method of branding can be used in the creation of area tourism products where it does not focus merely on building a product but also on the creation of a positive image of the product in its reception on the part of tourists 
[Szczepanowski 2009]. Hence, essential significance needs to be attributed to branding in the activities pursued by Destination Management Organizations [Borzyszkowski 2015]. This is confirmed among others by N. Morgan [2009]. According to the latter, the following aspects should be taken into consideration in the process of branding:

- DMO authorities must take over the initiative in the process of branding using government support (including local, regional and national governments);

- taking care of the opinions voiced by all the interested parties (stakeholders): their opinions must be taken into account in the process of branding.

In the case of activities aimed at destination branding, the creation of a system of visual identification plays an important part. J. Błaziak [2000], using the example of specific countries, defines this system as a "strong, strategic tool, which allows one to distinguish a given country in an attractive, unique and original manner, thus effectively contributing to the achievement of market success among other things". A graphical sign, i.e. a logo and a promotional slogan, constitutes the basis of such a system, as with one of the main elements of the brand.

Activities in the area of destination branding should be organized appropriately. This process concerns to a significant extent the division of responsibilities for its individual elements. However, a person or a team of people who have the greatest influence on decisions connected with branding should work in every DMO type organization (chiefly NTO). The research carried out by S. Kamann [2008] demonstrated that among the analysed DMOs, responsibility for branding is very dispersed. The largest number of replies was observed in the case of the appropriate marketing section (36.84\%), followed by: the Managing Director $(21.05 \%)$, the Management Board (18.42\%), the product department $(10.53 \%)$, external consultants $(4.39 \%)$, the quality management department $(1.75 \%)$ and other sections (7.02\%). Involvement of the representatives of the highest levels in a given organization clearly demonstrates the essential role attributed to branding in DMO activities. When locating branding in specific organizational sections, the appropriate "location" of this problem, i.e. in strictly marketing sections, is noteworthy.

To sum up the current discussion, it needs to be emphasized that present-day branding constitutes a mighty marketing tool in the activities of tourism reception areas [Kozak, Mazurek 2011]. This concerns especially the process of brand creation and building by the tourism reception area, where the construction of an adequate message and fulfilment of promises is the key objective. In the opinion of some authors (including [Berry 2000]), branding works perfectly in this respect. Furthermore, it has proved to be effective in the promotion of tourism in many countries including those with a lower development potential for this sector than in the case of Poland, thus making them tycoons of tourism. It is also considered by many specialists as a very effective way to quickly obtain an improvement of the rank, quality and effects of selected tourist sectors [Majewski 2012].

\section{Research methodology}

The empirical research was related to actions undertaken in the area of the creation and management of the state's tourism brand by 83 National Tourism Organizations that function in the area of five main tourism regions (according to UNWTO). The process of data collection and verification covers the years of 2013-2016. The research methods used included the following: a diagnostic survey method including a questionnaire technique (a questionnaire that contained 41 closed, open and mixed questions was the tool), a direct interview, and a statistical analysis. The empirical research was related solely to the functioning of those organizations which can be referred to as legitimate NTOs, i.e. those entities that meet the primary criteria for this type of organizations (including the pursuit of the chief objective: the promotion of a given country as an attractive tourism destination). No analyses of this type have so far been conducted. Therefore, the present study constitutes a completely novel approach to the functioning of National Tourism Organizations, it presents a much wider than ever spectrum of these organizations' areas of interest.

In this part of the article, the main criteria were presented which were taken into consideration in the selection of national tourism organizations for the purpose of the research. The following ones were included:

1. Functional criterion: as the basis for verification, the main functions attributed to national tourism organizations were accepted; firstly it was examined whether the promotion of a given country on foreign markets is included in these objectives.

2. Economic criterion: as the basis for verification, possession of an autonomous financial budget by a given NTO was accepted (regardless of the percentage share of funds from the state budget, from the private sector or any other sources).

3. Organizational criterion: as the basis for verification, it distinguished a given NTO in the organizational structure of the institution which it is 
directly subordinated to (e.g. a ministry or another national institution that is charge of a given NTO).

When verifying the number of NTO that take into account the criteria mentioned above, the main assumption was that only those entities are accepted in the research which meet at least one of these criteria, whereas in this case, this criterion must be the realization of the objectives by a given NTO in the scope of the widely understood promotion of a given country on markets abroad. This activity should be included in the statute (or another official document) of this organization. It should also be emphasized that a failure on the part of an individual NTO to comply with the remaining criteria does not mean that these organizations do not possess their budgets or do not function within the framework of the specified organizational structures. Difficulties obtaining official and reliable information on this subject may be one of the reasons.

Based on the accepted criteria, it was demonstrated that at present there are 111 typical NTOs on the central (national) level in the world, which mainly realize objectives attributed to this type organizations (including the promotion of a given country on foreign markets). These include 46 national organizations of the NTO type that operate in Europe and 65 NTOs that function on other continents.

Finally, 83 NTO (75.0\% of their total number) participated in the research process, out of which 39 (47.0\%) function in Europe while the remaining 44 $(53.0 \%)$ are NTOs that function on other continents (America-17.0\%, Africa-12.0\%, Asia and the Pacific $-20.5 \%$, the Middle East $-3.5 \%$ ). The division was made based on the UNWTO recommendations which distinguish five main tourism regions in the world, i.e. the European Region, the American Region, the Region of Asia and the Pacific, the African Region and the Region of the Middle East [Tourism Highlights... 2015]. Such a geographical spread of the NTOs analysed also allowed the author to accept the main division of the entities examined into two groups, i.e.:

- NTOs that function in Europe and

- NTOs that function on other continents (i.e. the rest of the world).

To sum up, 39 NTOs that function in European countries, $14 \mathrm{~s}$ NTO that function on the territory of both Americas, 10 NTOs that function in Africa, 17 s NTO that function in the Region of Asia and the Pacific and 3 NTOs that operate in the Middle East were accepted for further analysis. All the NTOs that qualified for the research meet at least one criterion accepted by the author in the form of the realization of their statutory objectives related to the promotion of a given country on foreign markets.

\section{Research results}

An analysis of the available studies concerning the functioning of national tourism organizations demonstrated that in the opinion of many authors, the realization of marketing activities with a special consideration of promotional activities constitutes the main objective of NTO type organizations. Within the framework of this objective, the following activities can be distinguished: formulation and implementation of marketing campaigns, promotion of the state on foreign markets, supervision and management of the activity of foreign branches, preparation and production of promotional publications and acting as a "link of cooperation" between the government and the private sector [Marczak 2013].

The analysis carried out by the author confirmed the thesis stating that the promotion of a given destination abroad is one of the most important present-day NTO activities. Among the organizations examined, as many as $94.0 \%$ indicated promotion on foreign markets as the key area of their activities. At the same time, taking into consideration the geographical criterion, it was demonstrated that this activity is equally important for both European and non-European NTOs. Similar results were also obtained in the second most important area of the activities of the NTOs examined, i.e. the preparation and implementation of various marketing campaigns $(82.0 \%)$. Therefore it can be observed that activities realized within the framework of the widely understood promotion constitute the most important aspect of the functioning of the NTOs analysed.

Furthermore, the analysis demonstrated that activities undertaken within the framework of branding constitute an important area of the interests of the examined NTOs; $74.7 \%$ of the organizations analysed expressed this opinion. Taking into account the geographical criterion, only a slightly larger participation was demonstrated in this group of NTOs that function outside Europe (38.6\%). Other objectives indicated by the NTOs as key include the following:

- taking activities tourism market research (42.2\%),

- support of the development of tourism products $(41.0 \%)$,

- cooperation with local and regional tourism organizations $(27.7 \%)$,

- organization of training for the benefit of tourist education $(26.5 \%)$,

- other activities (26.5\%); see Figure 1.

The research carried out on the sample of 83 organizations demonstrated that a clear majority of the analysed NTOs (75 organizations - 90.4\%) use 


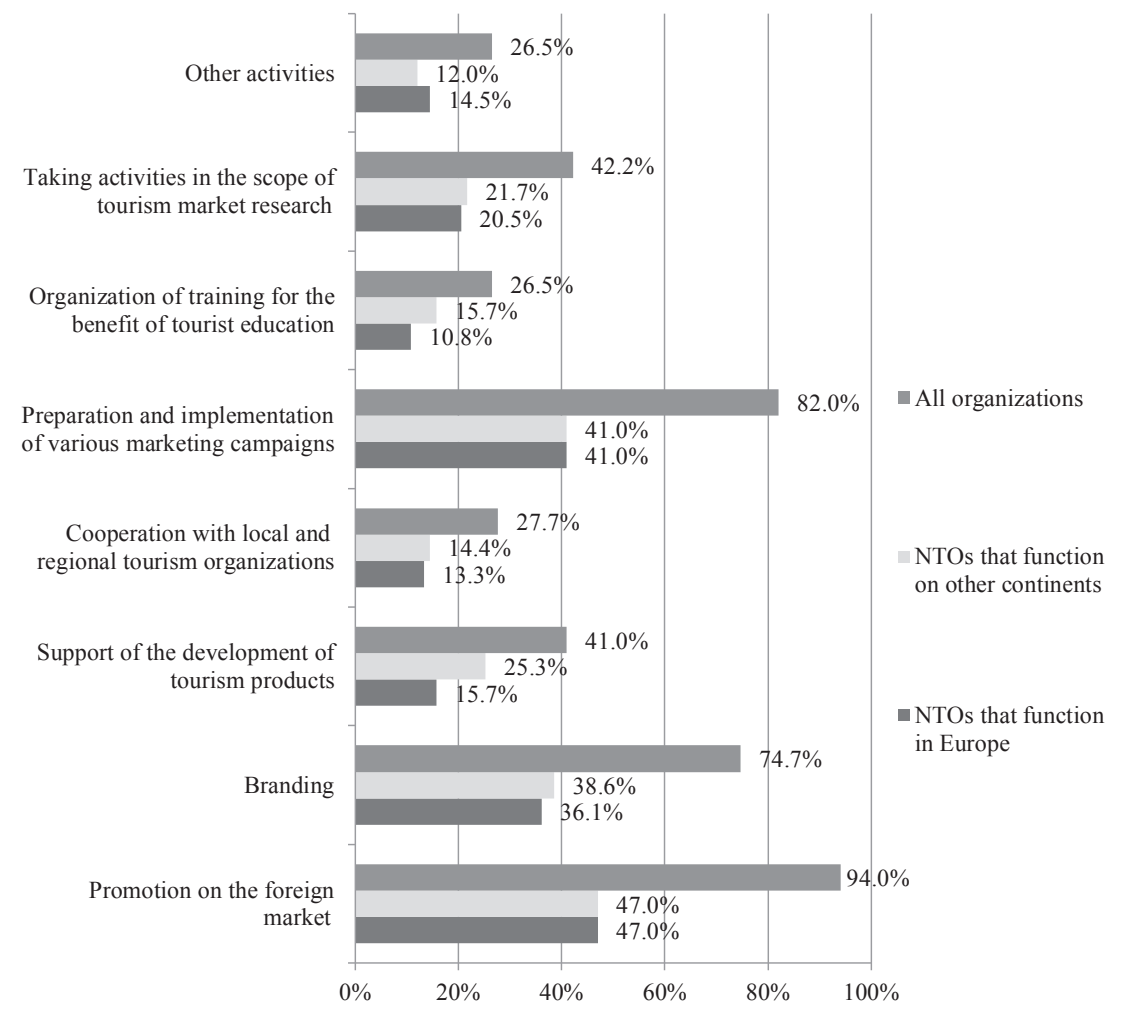

Fig. 1. Main areas of activities of the studied NTOs

Source: author's own research.

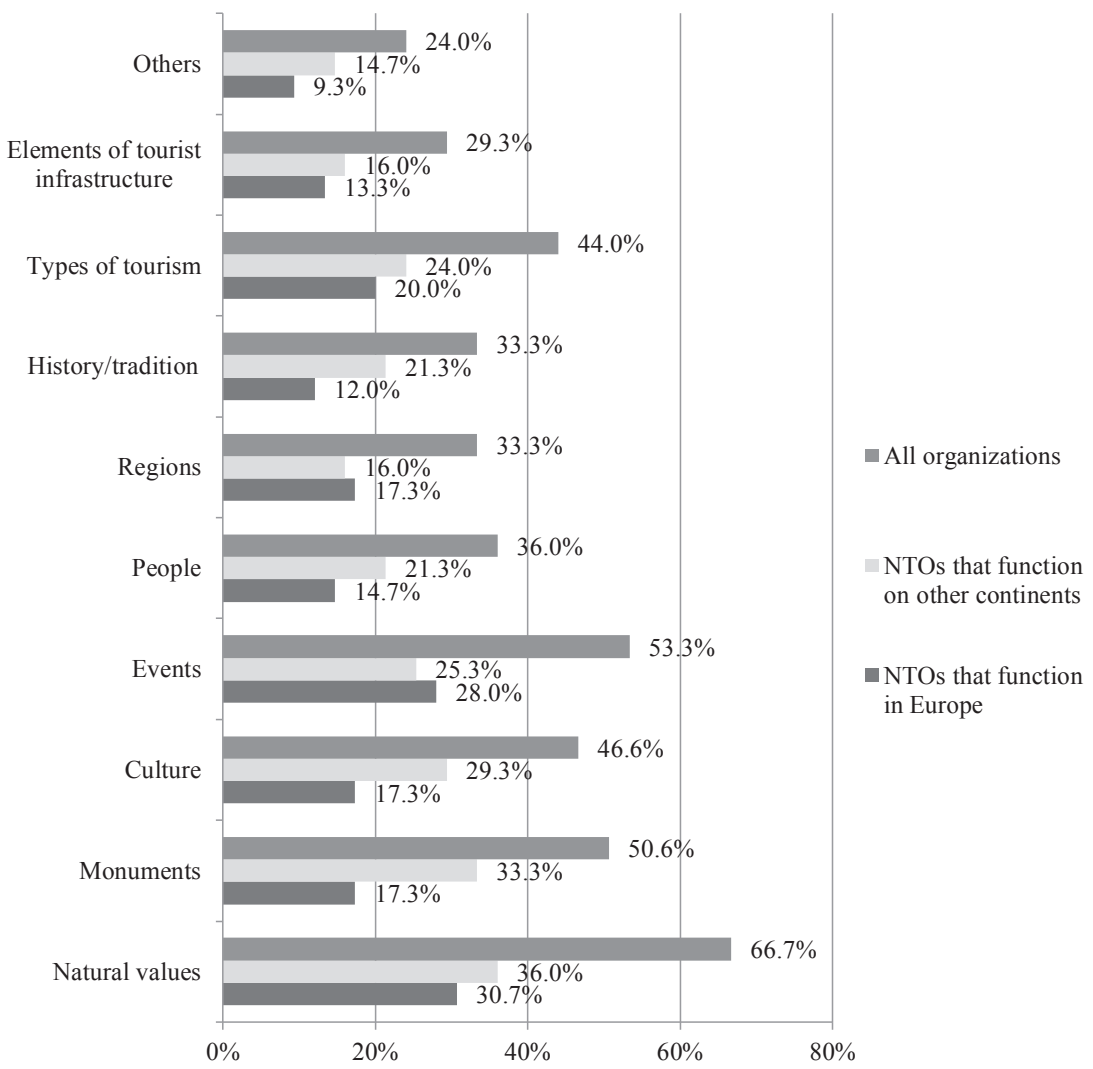

Fig. 2. Types of branded products used by the NTOs examined in promotional campaigns Source: author's own research. 
branded products in their promotional campaigns. Natural values $(66.7 \%)$ are the most frequently promoted as branded products. Events organized $(53.3 \%)$ ranked second, and monuments came third (50.6\%); see Figure 2.

In the first and the third case, non-European NTOs more frequently promoted this type of products, while in the case of events, these were the NTOs that function in Europe. It seems surprising that only $33.3 \%$ of the organizations examined promote in their campaigns as branded various tourism reception areas. By analysing the phenomenon examined with reference to the individual categories, it was demonstrated that natural values $(60.5 \%)$, events $(55.3 \%)$ and individual types of tourism $(39.5 \%)$ constitute the most frequently promoted branded products in the group of European NTOs. In the group of NTOs included in the category the "rest of the world", there were natural values (73\%), monuments $(67.6 \%)$ and culture $(59.5 \%)$.

The analysis carried out by the author made it possible to present the most important aspects of the practical use of branding by the examined national tourism organizations. It was demonstrated that this type activities are undertaken by the greater part of the organizations analysed (67). This constitutes $80.7 \%$ of the NTOs examined. The organizations that function in Europe $(53.7 \%)$ constitute the greater part in this group. As regards the total number of the organizations examined (83), greater participation was also observed in the case of European NTO (43.4\%); see Figure 3.

Among those national tourism organizations which do not undertake any activities within the framework of branding (16), NTOs from outside Europe constitute the vast majority $(81.3 \%)$. As regards the distribution of replies within the framework of the individual categories, it was demonstrated that branding is clearly more frequently used by European NTOs. Within the framework of this category, 92.3\% of the organizations use branding. In the case of NTOs included in the category of the "rest of the world", this percentage is smaller by 21.8 percentage points.

The analysis carried out also made it possible to determine the geographical scope of the activities undertaken by individual NTOs within the framework of branding. It was demonstrated that in a clear straight majority of organizations $(58-86.6 \%)$, this type of activities have a worldwide range (Figure 4). The organizations that operate in Europe (56.9\%) constitute a larger part in this group. As regards the total number of those NTOs that use branding (67 of organizations), the participation of the European NTOs is also greater $(49.3 \%)$. However, only $13.4 \%$ of the NTOs examined ( 9 organizations) conduct branding activities solely on their own continent. In this group, non-European organizations $(66.6 \%)$ constitute a greater part. When analysing the phenomenon examined within the individual categories, it can be clearly seen that considerably more NTOs that operate in Europe (91.7\%) implement branding on the world market. In the case of organizations included in the category of the "rest of the world", this percentage was $80.6 \%$. Such a wide scope of activities taken within the framework of branding by the majority of the NTOs examined may prove the rank and great significance of this type of initiatives in building the

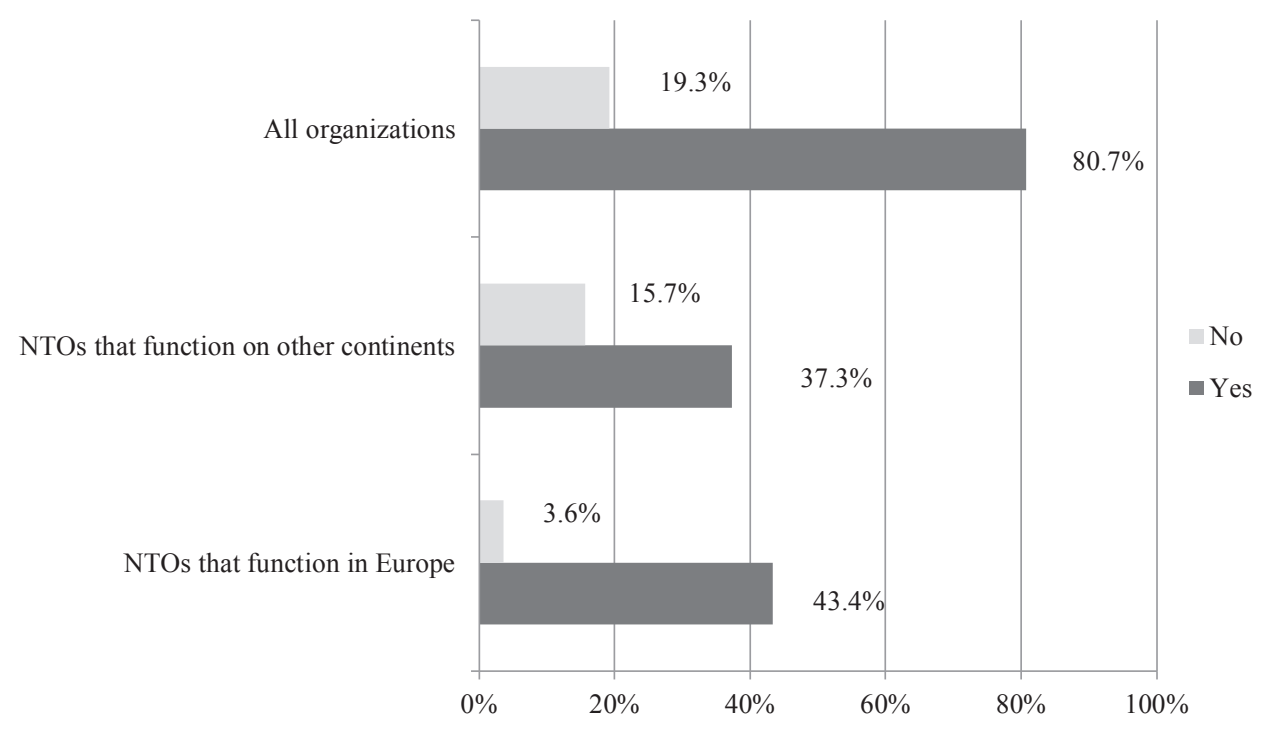

Fig. 3. Use of branding by the national tourism organizations examined

Source: author's own research. 


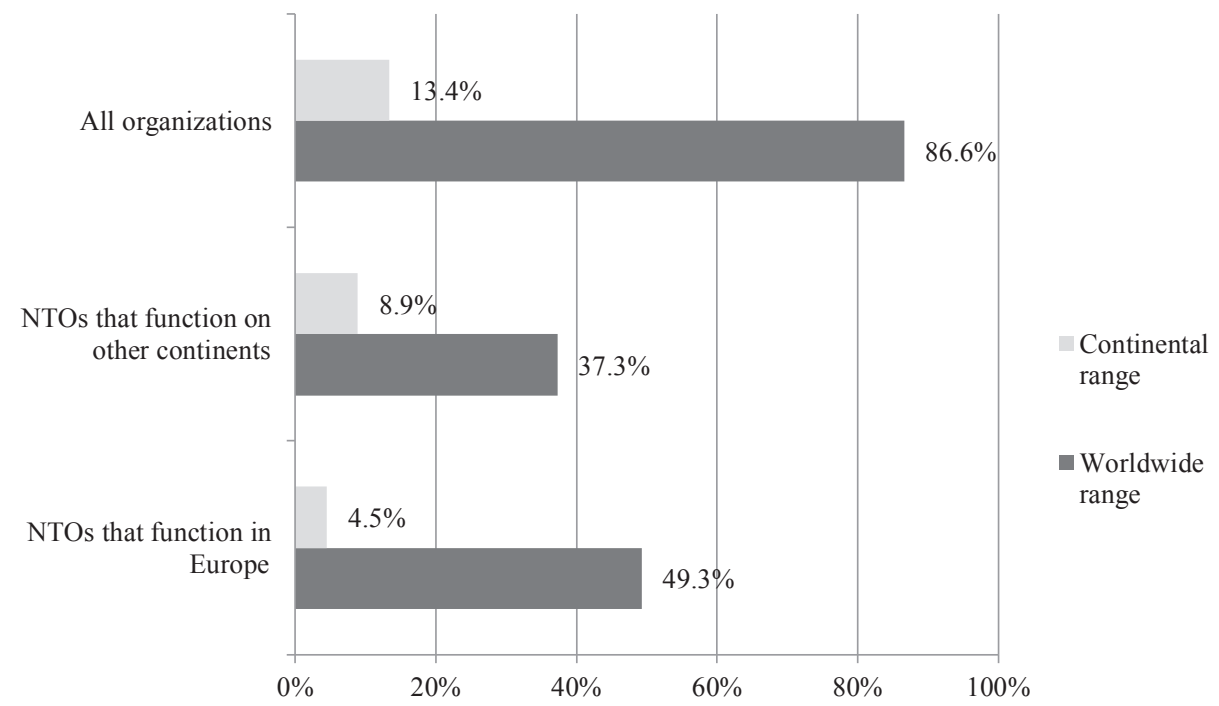

Fig. 4. Range of activities within the framework of branding which are taken by NTO entities examined

Source: author's own research.

awareness of the brand of national tourism reception areas in individual countries.

As previously demonstrated, the notion of branding is not explicit. Branding is quite frequently equated with various issues (including the image, identification, differentiating, a defined set of values, competitiveness of the tourism reception area identity, the essence of the tourism reception area etc.). The analysis carried out by the author confirmed the results of the research quoted above. It was demonstrated that the NTOs examined identify in different ways the notion of branding. It is most frequently equated with the image (58.2\%), with an emphasis on differences between competing tourism reception areas (31.3\%), an identification of a given tourism reception area (28.4\%) and a promotional campaign (28.3\%). By analysing the phenomenon examined within the framework of the individual categories, essential differences were demonstrated in the perception of branding by NTOs. These concern both those elements that branding is associated with and the percentage of those organizations that believe so. For the European organizations, branding constitutes above all an image $(50.0 \%$ of replies), showing the differences between competing tourism reception areas $(27.8 \%)$, an identification of the tourism reception area and visual elements ( $25.0 \%$ of replies each) as well as the essence of the tourism reception area and the promises which a given tourism reception area fulfils $(22.2 \%$ of replies each). The NTOs included in the category of the "rest of the world" equate to a great extent branding with the image $67.7 \%$ ), the promotional campaign (38.7\%), differences between competitive tourism reception areas $(35.5 \%)$, the essence and identification of a given tourism reception area (32.3\% of replies each) and a defined set of values as well as promises which branding fulfils $(29.0 \%$ of replies each).

Branding is a compound, multi-sided notion which can be used both by companies and tourism reception areas. Building a strong brand of the national tourism reception area is a long-term and complex process that involves many kinds of activities that use the assumptions of branding to a greater or lesser degree. The analysis carried out by the author permitted an identification of the main aspects of the use of this type of activities. It was demonstrated that among the national tourism organizations examined, the objectives of branding are frequently realized in the form of an efficiently functioning visual identification system (55 organizations: $82.0 \%$ of the replies from the NTOs examined). In this group, non-European organizations $(52.7 \%)$ have a slightly greater participation. As regards the total number of those NTOs that use branding (67), the participation of the NTOs included in the category the "rest of the world" is by $4.5 \%$ greater than for the European organizations. In the opinion of the examined NTOs, the following constitute other important aspects of the use of branding:

- realization of various promotional campaigns (67.1\% of the replies),

- positioning of the brand of the national tourism reception area $(61.2 \%)$,

- definition of the unique selling proposition (USP) $-50.7 \%$. 
- monitoring of the results of the brand (49.3\%),

- taking up various awareness campaigns (including educational activities $-46.3 \%$ ).

The activities within the framework of branding undertaken by national tourism organizations are aimed chiefly at building a strong brand of the national tourism reception area and the tourism image of the country that is positively received. However, this is a long-term and multifaceted activity. A strong brand of the tourism reception area is built on many planes simultaneously, while assuming that the interim deliverable achieved will yield the expected total effect. The analysis carried out by the author enabled an identification of the most important effects of the activities undertaken within the framework of branding according to the examined NTOs. It was demonstrated that the most frequently excepted effects of such activities are as follows:

- obtaining a desirable image of the national tourism reception area in the awareness of potential tourists ( $74.6 \%$ of the replies),

- $\quad$ strong national brand $(70.1 \%)$,

- strong brand of the national tourism reception area $(62.7 \%)$,

- identification by tourists of the unique benefits that characterize a given tourism reception area $(56.7 \%)$.

In conclusion, this part of the article covers the most important aspects of the activities of the national tourism organizations examined which are undertaken within the framework of branding. It was generally demonstrated that branding constitutes an essential part of the activities of the NTOs examined which are undertaken to build the strong points and image of the national tourism reception area brand and its competitive position. This statement applies both to those organizations that function in Europe and those that operate on other continents. In practice, $80.7 \%$ of the national tourism organizations examined use branding. Among the European organizations, this percentage was $92.3 \%$ and $70.5 \%$ for non-European ones. However, as a result of the analysis carried out, a number of differences between the European and non-European NTOs were observed as regards the realization of branding activities. In particular they concern the type of branded products used, the scope of activities undertaken within the framework of branding, an identification of branding with other elements, the use of the main elements of the visual identification system (the logo, the promotional slogan), the expected effects of branding as well as those activities that assess its quality. As regards activities undertaken within the framework of classic promotion (e.g. the instruments of promotion used), no essential differences between the organizations included in the accepted categories were demonstrated.

\section{Conclusions}

This article primarily presents the results of empirical research. The research results presented in the article constitute only a part of the comprehensive research carried out by the author related to the functioning of 83 national tourism organizations. This analysis was carried out in several main areas of activities of this type of organizations (including organizational, economic and marketing). However, it was branding and the most important aspects of its use in practice that constituted the core of the discussion. According to the author, it was demonstrated in the article that branding constitutes one of the most important areas of the activities of the present-day national tourism organizations. Undoubtedly this is one of the key elements of competition between tourist destinations and it plays an essential role in the whole management process of the tourism reception area. Therefore it seems obvious that national tourism organizations should verify their statutes in the scope of the main goals and objectives, and they should include in them the precisely defined tasks in the scope of branding which, apart from promotion, should be recognized as the basic sphere of NTO operations. The differences observed in the approach to the mechanisms of branding on the part of European and non-European organizations prove its multifaceted nature and dimensions that have not yet been examined. This is a relatively new notion that scholars have taken such a wide interest in only recently.

To sum up the current deliberations, it should be emphasized that branding constitutes the most important tool in the marketing of tourist reception areas by contributing to the increased competitiveness between destinations. However, it should be clearly emphasized that branding cannot be treated as a remedy for any problems connected with the development and promotion of tourist reception areas. Branding is not able to satisfy everybody. What is more, while making an attempt to do so, the effects are not satisfactory.

Conclusions based on the study may be used by those organizations that are responsible for the management process of the brand of a tourist reception area on different administration levels (including local, regional and national entities). 


\section{Bibliography}

Aaker D.A., 2002, Building Strong Brands, Simon and Schuster, London.

Analiza wyników badań wizerunku Polski i postrzegania polskiej marki na świecie. Zatożenia i rekomendacje do pozycjonowania Polski jako kraju docelowego podróży turystycznych na lata 2009-2015, Ekspertyza wykonana dla POT, 2008, Instytut Marki Polskiej, Warszawa.

Anholt S., 2009, Places, Identity, Image and Reputation, Palgrave Macmillan, London.

Anholt S., 2010, Great Brand Stories: Brand America, Marshall Cavendish, New York.

Anholt S., Spaven P., 2009, International Place Brand Yearbook, Palgrave Macmillan, Basingstoke.

Ashworth J.G., 2010, Towards Effective Place Brand Management: Branding European Cities and Regions, Edward Elgar Publishing Ltd.

Aziz N., Kefallonitis E., Friedman B.A., 2012, Turkey as a destination brand: perceptions of United States visitors, American International Journal of Contemporary Research, vol. 2, no. 9.

Bakri H.S., Soliman A.H.M., Al Bohairy H., 2010, Perception of Destination Branding Measures: A Case Study of Alexandria Destination Marketing Organizations, Volume 3, Number 2, Fayoum University, Aleksandria.

Berry L., 2000, Cultivating service brand equity, Journal of the Academy of Marketing Science, 28 (1).

Blain C., Levy S.E., Ritchie J.R.B., 2005, Destination branding: insights and practices from destination management Organizations, "Journal of Travel Research", vol. 43.

Błaziak J., 2000, Różnorodność pod jednym znakiem. Wizualna identyfikacja państwa, [in:] Gospodarka pod wtasna bandera. Patriotyzm w epoce globalizacji, ed. M. Boruc, Instytut Marki Polskiej, Warszawa.

Borzyszkowski J., 2015, Organizacje zarzadzajace obszarami recepcji turystycznej. Istota, funkcjonowanie, kierunki zmian, Wydawnictwo Politechniki Koszalińskiej, Koszalin.

Boyle D., 2003, Authenticity: Brands, Fakes, Spin and the Lust for Real Life, Flamingo, London.

Butler R., 1980, The Concept of a Tourist Area Cycle of Evolution: Implications for Management of Resources, The Canadian Geographer, 24(1).

Cai L., 2002, Cooperative Branding for Rural Destinations, Annals of Tourism Research, 29(3).

Cliffton R., Simmons J., 2004, Brands and Branding, (1st ed.), Profile Book Ltd., London.

Cretu I., 2011, Destination image and destination branding in transition countries: the Romanian tourism branding campaign Explore the Carpathian garden, University of York The York Management School Working Paper no. 66.

de Chernatony L., McDonald M., 2003, Creating Powerful Brands, 3rd edition, Elsevier, Butterworth Heinemann, Oxford.

Dębski M., 2013, Jakość jako element budowania marki destynacji podczas kryzysu gospodarczego, Współczesne Zarządzanie, nr 1.

Dinnie K., 2008, Nation Branding: Concepts, Issues, Practice, Butterworth-Heinemann, Oxford..

Dziedzic E., 1998, Obszar recepcji turystycznej jako przedmiot zarzadzania strategicznego, Monografie i Opracowania, nr 442, SGH, Warszawa.

Dziedzic E., 2012, Zaangażowanie finansowe sektora publicznego w rozwój podaży turystycznej w miastach, [in:] Turystyka na obszarach miejskich. Uwarunkowania rozwoju. Narze- dzia promocji, ed. T. Żabińska, Zeszyty Naukowe Wydziałowe Uniwersytetu Ekonomicznego w Katowicach, „Studia Ekonomiczne", Katowice.

Fan Y., 2006, Branding the nation: What is being branded?, Journal of Vacation Marketing, vol. 12.

Gabrielsson M., 2005, Branding strategies of born globals, Journal of International Entrepreneurship, no. 3.

Goeldner C., Ritchie J., McIntosh R. W., 2000, Tourism: Principles, practices, philosophies, 8th ed. Wiley, New York.

Govers R., 2009, From place marketing to place branding and back, Place Branding and Public Diplomacy, 7(4).

Govers R., Go F., 2009, Place Branding: Global, Virtual and Physical Identities, Constructed, Imagined and Experienced, Palgrave Macmillan, Basingstoke.

Green S., 2005, Defining West London - A case study of the initial stages of a strategic place branding exercise, CoDesign, 1(4).

Handbook on Tourism Destinations Branding, World Tourism Organization (UN WTO), 2009, European Travel Commission (ETC), Madrid, Spain.

Henderson J.C., 2007, Uniquely Singapore? A case study in destination branding, Journal of Vacation Marketing, 13(3).

Inskeep E., 1994, National and Regional Tourism Planning, Routledge, New York.

Ipsas A., 2012, The Tourism Destinations Marketing - A Mandatory Course for the Students of Tourism; www.steconomice. uoradea.ro.

Kamann S., 2008, Destination Marketing Organizations in Europe. An In-Depth Analysis, Destination Marketing Association International (DMAI) - NHTV Breda, University of Applied Sciences, Breda.

Kaplanidou K., Vogt Ch., 2003, Destination Branding: Concept and Measurement, Department of Park, Recreation and Tourism Resources, Michigan State University, August.

Kavaratzis M., Ashworth G., 2008, Place marketing: how did we get here and where are we going?, Journal of Place Management and Development", vol. 1, no 2.

Kesić T., Pavlić I., 2011, Tourism destination image formationthe Case of Dubrovnik, Croatia, Tržište, vol. XXIII, Faculty of Economics \& Business, University of Zagreb.

Kozak M., Mazurek M., 2011, Marka obszaru recepcji turystycznej: wartość marki, tożsamość marki, rozszerzanie marki $i$ co-branding, Folia Turistica, 25(2).

Majewski J., 2007, Struktury organizacyjne dla brandingu produktów terytorialnych, Rocznik Naukowy Wyższej Szkoły Turystyki i Rekreacji im. M. Orłowicza w Warszawie, tom 6, Wyższa Szkoła Turystyki i Rekreacji im. M. Orłowicza w Warszawie, Warszawa.

Majewski J., 2012, Branding $w$ zarzadzaniu popytem na turystyke wiejska, Zeszyty Naukowe Uniwersytetu Szczecińskiego, nr 698, „Ekonomiczne Problemy Usług”, nr 83, Szczecin.

Manente M., Minghetti V., 2006, Destination Management Organizations and Actors, [in:] Tourism Business Frontier, ed. D. Buhalis, C. Costa, Elsevier.

Marczak M., 2013, Branding $w$ turystyce - przyktady wykorzystania przez narodowe organizacje turystyczne $w$ wybranych krajach, [in:] Gospodarka turystyczna w regionie. Rynek turystyczny - wspótczesne trendy, problemy i perspektywy jego rozwoju, Prace Naukowe Uniwersytetu Ekonomicznego we Wrocławiu, nr 304, Wydawnictwo Uniwersytetu Ekonomicznego we Wrocławiu, Wrocław.

Marczak M., 2016a, Wykorzystanie brandingu przez wybrane, pozaeuropejskie narodowe organizacje turystyczne (NTO), Zeszyty Naukowe Wydziału Nauk Ekonomicznych Politechniki 
Koszalińskiej, nr 20, Wydawnictwo Uczelniane Politechniki Koszalińskiej, Koszalin.

Marczak M., 2016b, Branding in the Activities of European of National Tourism Organizations (NTO), Economic Problems of Tourism, vol. 4 (36), Uniwersytet Szczeciński, Szczecin.

Marczak M., 2017, Branding obszaru recepcji turystycznej i jego wykorzystanie $w$ działaniach narodowych organizacji turystycznych, [in:] Prace Naukowe Uniwersytetu Ekonomicznego we Wrocławiu nr 473, Gospodarka turystyczna $w$ regionie. Przedsiębiorstwo. Samorzą. Wspótpraca, Wydawnictwo Uniwersytetu Ekonomicznego we Wrocławiu, Wrocław.

Marczak M., Borzyszkowski J., 2009, Region (obszar) jako produkt turystyczny, Zeszyty Naukowe Instytutu Ekonomii i Zarządzania Politechniki Koszalińskiej, nr 13, Politechnika Koszalińska, Koszalin.

Middleton V.T.C., Hawkins R., 1998, Sustainable Tourism. A Marketing Perspective, Buttenworth-Heinemann, Oxford.

Morgan N., 2009, Destination branding or envisioning place reputation?, Institute for Tourism.

Morgan N., Pritchard A., 2000, Advertising in Tourism and Leisure, Butterworth-Heinemann, Oxford, UK.

Morgan N., Pritchard A., Piggott R., 2002, New Zealand, 100\% Pure: The Creation of a Powerful Niche Destination Brand, Journal of Brand Management, 9(4/5).

Nawrocka E., 2008, Wizerunek obszaru recepcji turystycznej, Zeszyty Naukowe Uniwersytetu Szczecińskiego, nr 521, Ekonomiczne Problemy Turystyki nr 11, Szczecin.

Ndlovu J., 2009, Branding as a Strategic Tool to Reposition a Destination: a Survey of Key Tourism Stakeholders in Zimbabwe, Unpublished PhD Thesis, University of Pretoria.

Niezgoda A., 2006, Obszar recepcji turystycznej w warunkach rozwoju zrównoważonego, Prace Habilitacyjne, $\mathrm{nr} 24$, Wydawnictwo Akademii Ekonomicznej w Poznaniu, Poznań.

Padurean L., 2010, Implementing destination governance, In: Proceedings Think Tank X: Networking for sustainable tourism, Vienna, Austria.

Page S., Connell J., 2009, Tourism. A Modern Synthesis, Cengage Learning EMEA.

Pike S., 2008, Destination branding: analysing brand equity for Queensland's Coral Coast, [in:] 18th Annual Council for Australian University Tourism and Hospitality Education Conference Where the Bloody Hell Are We?, 11-14 February 2008, Gold Coast International Hotel, Queensland.
Pike S., 2009, Destination brand positions of a competitive set of near-home destinations, Tourism Management, 30.

Pike S., Page S., 2014, Destination Marketing Organizations and destination marketing: A narrative analysis of the literature, Tourism Management, 41.

Pritchard A., Morgan N., 1998, Mood marketing - the new destination branding strategy: a case study of Wales, Journal of Vacation Marketing, 4(3).

Rainisto S., 2007, Success factors of Place Branding: A study of Place Marketing Practices, Study Report (www.sci.rainisto).

Ritchie J.B., Ritchie R.J.B., 1998, The Branding of Tourism Destination: Past Achievements and Future Trends, Reports of 48th Congress, AIEST, St-Gall.

Rizvi S.N.Z., Ahmad N., 2012: Internet as a potential tool for destination branding. A case study of Pakistan, Interdisciplinary Journal of Contemporary Research in Business, vol. 4, no 7.

Skoko B., Kovacic V., 2009, Koncept meke moci država i njegova primjena na Republiku Hrvatsku, Polemos, vol. 12.

Szczepanowski A.E., 2009, Marka produktu turystycznego jako źródto przewagi konkurencyjnej regionu, [in:] Marketing w rozwoju turystyki, ed. J. Chotkowski, Wydawnictwo Uczelniane Politechniki Koszalińskiej, Koszalin.

Szondi G., 2006, The role and challenges of country branding in transition countries: The Central and Eastern European experience, Place Branding and Public Diplomacy, 3(1).

Tan A.J.S., 2008, Destination Branding: Creating a Destination of Choice, "Perspectives in Asian Leisure and Tourism", vol. 1(1).

Tesławski M., 2013, Praktyka brandingu, Wydawnictwo „Słowa i myśli", Lublin.

Uhrenholt H., 2008, Destination Branding of NYC: Creating a Destination Brand Identity. Unpublished Master's Thesis, Faculty of Business Language Aarhus University, Denmark.

Żemła M., 2009, Nowe zastosowania marki jako narzędzia w marketingu produktu obszarów recepcji turystycznej, [in:] Prace Naukowe Uniwersytetu Ekonomicznego we Wrocławiu, nr 50, Gospodarka turystyczna w regionie Przedsiębiorstwo. Samorzad. wspótpraca, Wrocław.

Żemła M., 2012, The idea of destination brand licensing and the question of its effectiveness, Tourism and Hospitality Management, vol. 18, no 2 .

\section{BRANDING JAKO ISTOTNY ELEMENT PROCESU ZARZĄDZANIA OBSZARAMI RECEPCJI TURYSTYCZNEJ NA PRZYKŁADZIE WYBRANYCH PAŃSTW}

Streszczenie: Celem artykułu jest ukazanie roli, jaką w procesie zarządzania obszarem recepcji turystycznej odgrywa branding. Analizą objęto działania podejmowane w ramach brandingu przez narodowe organizacje turystyczne (NTO), funkcjonujące w wybranych krajach. Ukazano je w kontekście ich znaczenia dla przebiegu kompleksowego procesu zarządzania obszarami recepcji turystycznej. Główną metodą badawczą wykorzystaną w artykule jest metoda sondażu diagnostycznego z zastosowaniem techniki ankietowej. W artykule wykorzystano ponadto analizę danych wtórnych oraz analizę dostępnej literatury przedmiotu. Przeprowadzona analiza wykazała m.in., że branding stanowi bardzo ważny element procesu zarządzania marką turystyczną państw. Zdecydowana większość badanych narodowych organizacji turystycznych $(92,3 \%)$ uznała działania podejmowane w ramach brandingu za jeden z ważniejszych aspektów zarządzania marką obszarów recepcji turystycznej, podejmując jednocześnie wiele rzeczywistych działań w tym zakresie.

Słowa kluczowe: branding, marka, zarządzanie obszarem recepcji turystycznej, narodowa organizacja turystyczna. 